\title{
An evaluation of three methods of typing organisms of the genus Proteus
}

\author{
OONAGH TRACY1 AND E. JEAN THOMSON \\ From the Department of Bacteriology, Royal Infirmary, Glasgow
}

SYNOPSIS An assessment of three simple methods of typing Proteus strains is described. The methods chosen were biochemical typing, bacteriocine typing, and typing by means of the Dienes phenomenon. Dienes typing was deemed to be superior to biochemical typing and bacteriocine typing.

A brief discussion on the relationship between the Dienes phenomenon and bacteriocine production is appended.

Proteus infections in hospital practice may present a therapeutic problem, since Proteus species readily develop resistance to antibiotics (Carpenter, 1964). The extent to which Proteus cross-infection occurs is hard to assess, and in evaluating this problem difficulty arises because the infection may be exogenous or endogenous; since it is impossible to distinguish between these two routes of infection this problem must remain unsolved until a suitably simple and accurate typing system is made available.

Several methods have been used: serology (Belyavin, Miles, and Miles, 1951; Krikler, 1953; Nestoresco, Popovici, Racovitai, Dimitriu, Floresco, Mermezan, Filipesco, Thomas, and Dragan, 1963), biochemistry (Kippax, 1957; Huang, 1966), Dienes typing (Krikler, 1953; Story, 1954; De Louvois, 1969; Skirrow, 1969). Bacteriocine typing (Cradock-Watson, 1965) and bacteriophage typing in conjunction with biochemistry (France and Markham, 1966) have all been employed.

We wished to select a method suitable for a diagnostic laboratory rather than a reference laboratory, and accordingly chose the simplest of the available methods for study. For this reason, serology and bacteriophage typing were excluded as being too cumbersome for such a purpose. The remaining methods-biochemistry Dienes typing, and bacteriophage typing-were selected for evaluation. It was thought that these methcds were particularly suitable, as they required only simple equipment and were not time-consuming.

'Present address: Sectoral Bacteriological Laboratory, Victorla Infirmary, Langside, Glasgow, $\mathbf{S 2}$.

Received for publication 9 June 1971.

\section{Materials and Methods}

STRAINS OF BACTERIA

One hundred and fifty Proteus isolates were obtained from clinical specimens over a six-month period. Of these 75 were random isolates and the remainder were selected from two units in the hospital where cross infection was thought to be occurring. These were the Burns Unit and the Urology Department.

Where more than one isolate was made from an individual patient only the original one was examined, any other isolates being excluded from the investigation.

IDENTIFICATION OF SPECIES AND BIOCHEMICAL T Y PING

Cultures were screened for urease production (Christensen's medium) and phenylalanine deaminase production (phenylalanine agar slopes), and, in addition, species identification of 83 strains was carried out.

For species identification five further tests were used. These were indole production, hydrogen sulphide production, gelatin liquefaction, and fermentation of maltose and mannitol. For these reactions the multitest media of Huang (1966) were employed. Proteus vulgaris (NCTC 4363), Proteus mirabilis (NCTC 5887), Proteus rettgeri (NCTC 7475), and Proteus morganii (NCTC 235) were used as controls. These were obtained from the National Collection of Type Cultures, Central Public Health Laboratory, Colindale, London, NW9. 
TYPING BY THE DIENES PHENOMENON

The medium used was nutrient agar (Oxoid columbia agar base), an agar concentration of $1 \%$ being found to be most satisfactory. The inocula were six-hour Hartley's digest broth cultures. One loopful of each of three cultures was placed on a nutrient agar plate, these inocula being kept as far apart as possible. Of these three cultures, one was an unknown test strain, and the others were two cultures which were known to be dissimilar and which would give a positive Dienes reaction. The plates were incubated overnight at $37^{\circ} \mathrm{C}$, and then examined for the presence of demarcation lines, using a bright light and against a dark background.

\section{BACTERIOCINE TYPING}

The method was that of Cradock-Watson (1965) and the medium was Oxoid CM7 MacConkey agar. The results were read according to the criteria of Abbott and Shannon (1958). Attempts to assay the potency of the bacteriocines detected were made, using both the method of McGeachie (1965) and also that of Osman (1965). For the method of McGeachie, the recommended medium and, in addition, Oxoid CM7 MacConkey agar, were used, since it was known that the composition of medium has a marked effect on bacteriocine yield (McGeachie and McCormick, 1963).

\section{Results}

\section{BIOCHEMISTRY}

Eighty-three isolates were subjected to biochemical typing. Of these, $76(91.5 \%)$ were identified as Proteus mirabilis, three $(3.6 \%)$ as Proteus vulgaris, three $(3.6 \%)$ as Proteus morganii, and one $(1.2 \%)$ as Proteus rettgeri.

For practical purposes, therefore the problem consisted of the subdivision of the 76 isolates identified as Proteus mirabilis. These were divided into biotypes, $63(82.9 \%)$ conforming to biotype 1 and $13(17 \cdot 1 \%)$ to biotype 2 of the France and Markham scheme. No members of biotypes 3 or 4 were found.

DIENES TYPING

The Dienes reaction is negative when the 'haloes' of spreading colonies merge imperceptibly and positive when a narrow zone of inhibition can be seen where they meet. Dissimilar cultures give a positive Dienes reaction and the negative reaction is the reaction of identity. The results were interpreted accordingly.

Using this method, 100 isolates were divided into 27 types, of which seven were the most common. These seven types formed the Dienes panel, and a total of 150 isolates was tested against this panel. The results of Dienes typing are shown in Tables I and II. It can be seen that there was evidence of cross infection in both the Burns Unit and the Urology Department.

\begin{tabular}{llll}
\hline & Random Strains & Selected Strains \\
\cline { 3 - 4 } & & Burns Unit & Urology Dept. \\
\hline $\begin{array}{l}\text { Total number } \\
\text { of strains }\end{array}$ & 75 & 22 & 53 \\
$\begin{array}{l}\text { Number typable } \\
\text { Percentage }\end{array}$ & 16 & 17 & 28 \\
typable & 21 & 77 & 53 \\
\hline
\end{tabular}

Table I Results of Dienes typing

\section{BACTERIOCINE TYPING}

One hundred isolates were tested; the indicator strains of the Cradock-Watson typing system were used to detect bacteriocine production. None of the isolates was typable by this method. Only six produced bacteriocines active against the CradockWatson indicator panel, and these gave patterns not recognizable as those of any known type.

It was felt that the results of bacteriocine typing might be improved if an indicator panel composed of locally isolated strains was employed. The group of

\begin{tabular}{|c|c|c|c|c|c|c|}
\hline \multirow[t]{3}{*}{ Type } & \multicolumn{2}{|c|}{ Random Strains } & \multicolumn{4}{|c|}{ Selected Strains } \\
\hline & & & \multicolumn{2}{|c|}{ Burns Unit } & \multicolumn{2}{|c|}{ Urology Department } \\
\hline & No. & $\%$ & No. & $\%$ & No. & $\%$ \\
\hline 1 & 9 & $12(12)$ & 1 & $5(4 \cdot 54)$ & 5 & $9(9 \cdot 43)$ \\
\hline 4 & - & - & 1 & $5(4 \cdot 54)$ & 5 & $9(9.43)$ \\
\hline 29 & - & - & - & - & 5 & $9(9.43)$ \\
\hline 34 & 1 & $1(1 \cdot 33)$ & 1 & $5(4 \cdot 54)$ & 7 & $13(13 \cdot 20)$ \\
\hline 62 & 4 & $5(5 \cdot 33)$ & - & - & 3 & $6(5.66)$ \\
\hline $1 \mathrm{~A}$ & 2 & $3(2.66)$ & 13 & $59(59.09)$ & 3 & $6(5.66)$ \\
\hline $4 A$ & - & - & 1 & $5(4 \cdot 54)$ & - & - \\
\hline N.T. & 59 & $79(78 \cdot 66)$ & 5 & $23(22 \cdot 72)$ & 25 & $47(47 \cdot 17)$ \\
\hline Total & 75 & & 22 & & 53 & \\
\hline
\end{tabular}

Table II Distribution of types among Dienes typable strains 
100 isolates subjected to bacteriocine typing had already been divided by Dienes typing into 27 types. These 27 types were now employed as indicators for the 100 random isolates in bacteriocine typing. It was found that 19 of the 100 isolates produced bacteriocines active against a member or members of this panel. Eight producer patterns were obtained, and designated types 1-8. Of these, 11 were type 1 , two type 7, and the rest one each of the remaining types. The 11 type 1 strains were distributed at random in the hospital.

\section{Discussion}

In the selection of a Proteus typing method for routine use, it was felt that biochemical typing had failed to provide sufficient differentiation of strains to be useful for epidemiological purposes.

The Dienes method has the advantage that previously unrecognized types can be identified as being similar. However, the method may give rise to problems in practice; strains sometimes enter a nonswarming phase, known as the ' $B$ ' phase (Belyavin, 1951). If, therefore, two Proteus strains are subjected to the Dienes method of typing the swarming growth of one strain may obscure the fact that the second strain is in the non-swarming ' $\mathrm{B}$ ' phase, and the two organisms may be wrongly regarded as being identical. The method employed in this study was an attempt to avoid this pitfall by incorporating two strains known to give a positive Dienes reaction, to act as a control in each test. This avoids any fallacy in the interpretation of the test, but the occasional appearance of the ' $B$ ' phase in test strains may cause difficulty in practice.

A source of error which may occur in the stroke plate method of bacteriocine typing has been pointed out by McGeachie and McCormick (1967). These authors advocate extraction of bacteriocine, lest weak bacteriocine production should be missed. We were not successful in preparing extracts from our strains and so were unable to assess the bacteriocine typing of $B$. proteus by this method. This is unfortunate, since it may be that the disappointing bacteriocine typing results which we obtained were due to weak, undetected bacteriocine production.

None of our strains was typable by the CradockWatson indicator panel. This, coupled with the fact that a relatively large number of Dienes types was found, might indicate that a considerable variety of types of $B$. proteus exist. Consequently, it might be unreasonable to expect that a typing method suitable for use in one area would be applicable in another epidemiological situation. We believe, therefore, that at present Dienes typing provides the most satisfactory method of Proteus typing, since it is one which can be applied to any group of isolates.

A consideration of the relationship between bacteriocine production and the Dienes phenomenon is also pertinent. The original observations of Dienes on the phenomenon which bears his name were made during a study on reproductive processes in Proteus cultures (Dienes, 1946, 1947). It appeared to Dienes that his findings could be attributed to an unusual reproductive process in Proteus strains. Subsequently, Krikler (1953) showed that the Dienes phenomenon could be related to the $\mathbf{H}$ antigen composition of strains of $B$. proteus. This work, however, merely reflects a correlation between two methods of typing Proteus isolates, and cannot be considered to provide an explanation of the phenomenon. Another possibility is that the Dienes phenomenon is due to bacteriocine production. If this were the case, each type could be expected to produce bacteriocines active against all other Dienes types. This prediction was not fulfilled in our study. Though it is true that failure to demonstiate bacteriocine production may have been a reflection of weak bacteriocine potency, the results obtained cannot be considered to confirm the hypothesis that the Dienes phenomenon might be due to bacteriocine activity.

Our thanks are due to Dr J. C. J. Ives for his interest and encouragement and we are most grateful to $\mathrm{Dr}$ J. E. Cradock-Watson, Public Health Laboratory, Withington Hospital, Manchester, who very kindly supplied indicator strains and details of the bacteriocine typing system. We also wish to thank the Director of the National Collection of Type Cultures for providing the type strains of Proteus. Requests for reprints should be addressed to Dr E. J. Thomson, Department of Bacteriology, Royal Infirmary, Glasgow, C4.

\section{References}

Abbott, J. D., and Shannon, R. (1958). A method for typing Shigella sonnei using colicine production as a marker. J. clin. Path., 11, 71-77.

Belyavin, G., Miles, E. M., and Miles, A. A. (1951). The serology of fifty strains of Proteus vulgaris. J. gen. Microbiol., 5, 178-196.

Belyavin, G. (1951). Cultural and serological phases of Proteus vulgaris. J. gen. Microbiol., 5, 197-207.

Carpenter, K. P. (1964). The Proteus-providence group. In Recent Advances in Clinical Pathology, edited by S. C. Dyke. Series IV, ch. 2, pp. 13-24.

Cradock-Watson, J. E. (1965). The production of bacteriocines by Proteus species. Zbl. Bakt., I. Abt. (Orig.), 196, 385-388.

De Louvois, J. (1969). Serotyping and the Dienes reaction on Proteus mirabilis from hospital infections. J. clin. Path., 22, 263-268.

Dienes, L. (1946). Reproductive processes in Proteus cultures. Proc. Soc. exp. Biol. (N.Y.), 63, 265-270.

Dienes, L. (1947). Further observations on reproduction of bacilli from large bodies in Proteus cultures. Proc. Soc. exp. Biol. (N.Y.), 66, 97-98.

France, D. R., and Markham, N. P. (1968). Epidemiological aspects of Proteus infections with particular reference to phage typing.
J. clin. Path., 21, 97-102. 
Huang, C. T. (1966). Multitest media for rapid identification of Proteus species with notes on biochemical reactions of strains isolated from urine and pus. J. clin. Path., 19, 438-442.

Kippax, P. W. (1957). A study of Proteus infections in a male urological ward. J. clin. Path., 10, 211-214.

Krikler, M. S. (1953). The serology of Proteus vulgaris. PhD Thesis, London University.

McGeachie, J. (1965). Bacteriocin typing in urinary infection. $Z b l$. Bakt., I. Abt. (Orig.), 196, 377-384.

McGeachie, J., and McCormick, W. (1963). Comparison of colicine production and diffusion on different solid media. J. clin. Path., 16, 278-280.

McGeachie, J., and McCormick, W. (1967). Importance of potency in typing by colicine production. J. clin. Path., 20, 887-891.

Nestoresco, N., Popovici, M., Racovita, D., Dimitriu, D. Floresco, D., Mermezan, E., Filipesco, S., Thomas, E., and Dragan, T. (1963). Recherches sur les germes du groupe Proteus isolés des infections urinaires. Aspects of cliniques et epidemiologiques. Acta urol. belg., 31, 469-481.

Osman, M. A. M.(1965). Pyocyine typing of Pseudomonas aeruginosa J. clin. Path., 18, 200-202.

Skirrow, M. B. (1969). The Dienes (mutual inhibition) test in the investigation of Proteus infections. J. med. Microbiol., 2, 471-477.

Story, P. (1954). Proteus infections in hospital. J. Path. Bact., 68, 55-62.

\section{Reports and Bulletins prepared by the Association of Clinical Biochemists}

The following reports and bulletins are published by the Association of Clinical Biochemists. They may be obtained from The Administrative Office, Association of Clinical Biochemists, 7 Warwick Court, Holborn, London, WC1R 5DP. The prices include postage, but air mail will be charged extra. Overseas readers should remit by British Postal or Money Order. If this is not possible the equivalent of $50 \mathrm{p}$ is the minimum amount that can be accepted.

SCIENTIFIC REPORTS

3 Automatic Dispensing Pipettes. An assessment of 35 commercial instruments 1967 P. M. G. BROUGHTON, A. H. GOWENLOCK, G. M. WIDDOWSON, and K. A. AHLQUIST $85 \mathrm{p}(\$ 12)$

4 An Evaluation of five Commercial Flame Photometers suitable for the Simultaneous Determination of Sodium and Potassium March 1970 P. M. G. BROUGHTON and J. B. DAWSON $85 \mathrm{p}(\$ 2)$

SCIENTIFIC REVIEWS

1 The Assessment of Thyroid Function March 1971 F. V. FLYNN and J. R. HOBBS $62 \frac{1}{2} \mathrm{p}(\$ 1.50)$

\section{TECHNICAL BULLETINS}

9 Determination of Urea by AutoAnalyzer November 1966 RUTH M. HASLAM $42 \frac{1}{2} \mathrm{p}(\$ 1)$

11 Determination of Serum Albumin by AutoAnalyzer using Bromocresol Green October 1967 B. E. NORTHAM and G. M. WIDDOWSON $42 \frac{1}{2} \mathrm{p}(\$ 1)$

13 An Assessment of the Technicon Type II Sampler Unit March 1968 B. C. GRAY and G. K. McGOWAN $42 \frac{1}{2} \mathrm{p}(\$ 1)$

14 Atomic Absorption Spectroscopy. An outline of its principles and a guide to the selection of instruments May 1968 J. B. DAWSON and P. M. G. BROUGHTON $42 \frac{1}{2} \mathrm{p}(\$ 1)$
15 A Guide to Automatic Pipettes (2nd edition) June 1968 P. M. G. BROUGHTON $42 \frac{1}{2} \mathrm{p}(\$ 1)$

16 A Guide to Automation in Clinical Chemistry May 1969 P. M. G. BROUGHTON $62 \frac{1}{2} \mathrm{p}(\$ 1.50)$

17 Flame Photometers (2nd edition) 1969 P. WILDING $62 \frac{1}{2} \mathrm{p}(\$ 1.50)$

18 Control Solutions for Clinical Biochemistry (4th edition) March 1970 P. M. G. BROUGHTON $62 \frac{1}{2} \mathrm{p}$ $(\$ 1.50)$

19 Spectrophotometers. A comparative list of low-priced instruments readily available in Britain May 1970 C. E. WILDE and P. SEWELL $62 \frac{1}{2} \mathrm{p}(\$ 1.50)$

20 Quantities and Units in Clinical Biochemistry June 1970 P. M. G. BROUGHTON $62 \frac{1}{2} \mathrm{p}(\$ 1.50)$ More than 30 copies in units of 10 at $20 p$

21 Filter Fluorimeters: A comparative list of 18 instruments September 1970 H. BRAUNSBERG and $s$. $S$. BROWN $62 \frac{1}{2} \mathrm{p}(\$ 1.50)$

22 Bilirubin standards and the Determination of Bilirubin by Manual and Technicon AutoAnalyzer Methods. January 1971 BARBARA BILLING, RUTH HASLAM and N. WALD $62 \frac{1}{2} \mathrm{p}(\$ 1.50)$

23 Interchangeable Cells for Spectrophotometers and Fluorimeters September 1971 E. S. BROWN and A. H. GOWENLOCK $62 \frac{1}{2} \mathrm{p}(\$ 1.50)$ 